\title{
Economic Value Added (EVA) as an Indicator for Financial Decisions
}

\author{
Cristina Mihaela ONICA ${ }^{\star}$
}

\begin{tabular}{l}
\hline \multicolumn{1}{c}{ A R T I C L E I N F O } \\
\hline Article history: \\
Accepted December 2019 \\
Available online December 2019 \\
\hline JEL Classification \\
G32, G33, C39 \\
Keywords: \\
Economic added value, Net \\
operating profit, The cost of capital, \\
Performance, Analysis, Capital \\
\hline
\end{tabular}

\begin{abstract}
A B S T R A C T
The economic added value is an indicator that represents a performance measurement of the real economic profit obtained by a company, which allows to predict the company's success or failure over a certain period of time. The use of EVA in the measurement of a company's financial and economic performances is considered to be better due to the fact that it offers a basis for a comparison between companies, by taking into account both the cost of capital and the company's degree of risk. The study of economic value became a widely debated issue nowadays because the main objective of any company is maximizing shareholders'profits.
\end{abstract}

(c) 2019 EAI. All rights reserved.

\section{Introduction}

The economic added value indicator represents a capital allocation tool and it may reflect shareholders' equity loss, if the company doesn't have a rate of return which is at least equal to the average rate of return on the capital market, fact that can determine the shareholders to invest in other companies. The economic added value is extremely sensitive to the component that concerns the cost of shareholders' equity and it is less sensitive to the component that regards the cost of the debt under normal circumstances.Its size and variability are strongly affected by the company's growth policies because of the leverage and it shows more instability than the economic rate of return (on investment), being directly connected to the financial rate of return (on shareholders' equity).

\section{Economic added value analysis and calculation}

The calculation method exemplification was carried out by using the data published by the abovementioned companies in the annual reports on the Bucharest Stock Exchange site. The calculation of each indicator was made over a period of two years, 2017 - 2018. The present paper aims at highlighting and reinforcing the usefulness of the EVA indicator and the relevance of the obtained results.

The economic added value, a term taken from the American accountancy, represents the company's financial performance assessment, which expresses its residual wealth and it can be determined by deducting the cost of capital from the net operating profit (Net Operating Profit After Taxes - NOPAT) and the gross operating profit, respectively, according to the relation:

\section{Vea $=$ Net operating profit $-($ Capital X Cost of capital)}

The economic added value indicator, created by Stern-Stewart, has the formula EVA = NOPAT - Cost of invested capital. NOPAT (Net Operating Profit after Tax) is NOPAT $=$ Net Profit after Tax + after tax Interest Expense - after tax Interest Income. In other words, NOPAT represents the company's result, on the condition that it doesn't have any financial debts and that the tax or the operating profit is already calculated by taking into account financial expenses and revenues.

The net operating profit (Bnet op) is determined by deducting the income tax (Ip) from the gross operating profit (Rexp):

$$
\text { Bnet op }=\text { Rexp }-I p=\text { Vexp }- \text { Chexp }-I p
$$


The cost of capital includes the cost of shareholders' equity and the cost of debt, becoming the opportunity cost of the invested capital, which determines the way in which the company can increase its revenues (by investment in any other part with a similar degree of risk or by loan).

The cost of capital includes the weighted average costof capital (WACC) of the utilized funding sources, which is determined as the weighted arithmetic mean (Cmpc) of the shareholders' equity and of the borrowed capital cost, depending on each category's weight (Si) and on the related remuneration rate (ri).

$$
\mathrm{Cmpc}=\frac{\sum \mathrm{Six} \text { ri }}{100}=\frac{\mathrm{C}}{\mathrm{Ci}} \times \mathrm{Rf}+\frac{\mathrm{D}}{\mathrm{Ci}} \mathrm{x} \mathrm{dx}(1-\mathrm{i})
$$

which:

$\mathrm{C}=$ shareholders' equity;

$\mathrm{D}=$ total debts;

$\mathrm{Ci}=$ invested capital $=\mathrm{C}+\mathrm{D}$;

$\mathrm{d}=$ interest rate;

$\mathrm{i}=$ tax rate.

In this case the added economic value, which represents the real economic profit obtained by the company, relates to the entire capital used for financing and it is determined by the difference: $\boldsymbol{V e a}=(\boldsymbol{R i}-\boldsymbol{C m p c}) \boldsymbol{x} \boldsymbol{C i}$, where:

$\mathrm{Ri}=$ return on total invested capital; $\mathrm{Cmpc}=$ weighted average cost of capital.

\section{The EVA calculation and analysis for Biofarm S.A.}

Biofarm has a competitive portfolio of over 200 products that cover 61 therapeutic areas and continuously invests in media, commercial and marketing campaigns to promote its products. Occupying a stable position on the Romanian pharmaceutical market, Biofarm S.A. aims at improving its position on the international market as well, being present in 12 countries and its expansion continues.

In order to calculate the economic added value for the established time period, the data from the annual financial situations were used and the following indicator values from Table no. 1 were obtained:

Table 1. The EVA calculation for Biofarm S.A. for the time period $2017-2018$

\begin{tabular}{|c|c|c|c|c|c|}
\hline \multirow[t]{2}{*}{ No. } & \multirow{2}{*}{$\begin{array}{c}\text { Indicators } \\
\text { (thousands of lei) }\end{array}$} & \multicolumn{2}{|c|}{ Financial year } & \multirow{2}{*}{$\begin{array}{l}\text { Deviation } \\
( \pm \Delta)\end{array}$} & \multirow{2}{*}{$\begin{array}{l}\text { Indices } \\
(\%)\end{array}$} \\
\hline & & 2017 & 2018 & & \\
\hline 1. & Gross operating profit (Rexp) & 16.416 .857 & 22.587 .898 & +6.171 .041 & 137,58 \\
\hline 2 & Income tax (Ip) (-) & 2.954 .600 & 4.090 .568 & +1.135 .968 & 138,44 \\
\hline 3 & Net operating profit (Bnop) & 13.462 .257 & 18.497 .330 & +5.035 .073 & 137,40 \\
\hline 4 & Tax rate (i) $(2 / 1)$ & 0,18 & 0,18 & 0 & 100,00 \\
\hline 5 & Total invested capital (Ci) & 196.930 .710 & 208.195 .930 & +11.265 .220 & 105,72 \\
\hline 6 & $\begin{array}{l}\text { Return on invested capital (Ri) (3/5) } \\
(\%)\end{array}$ & 6,83 & 8,88 & $+2,05$ & 130,01 \\
\hline 7 & $\begin{array}{l}\text { Shareholders' equity (C) }(7 / 5) * 100 \\
-\quad \text { Share in total capital (Scp) }(\%) \\
\end{array}$ & $\begin{array}{r}164.539 .257 \\
83,55 \\
\end{array}$ & $\begin{array}{r}175.887 .136 \\
84,48 \\
\end{array}$ & $\begin{array}{r}+11.347 .879 \\
+0,93 \\
\end{array}$ & $\begin{array}{l}106,89 \\
101,11 \\
\end{array}$ \\
\hline 8 & Return on equity (Rf) $(3 / 7)(\%)$ & 8,18 & 10,51 & $+2,33$ & 128,48 \\
\hline 9 & $\begin{array}{l}\text { Total debt (D) }(9 / 5)^{*} 100 \\
-\quad \text { Share in total capital }(\mathrm{Sd})(\%) \\
\end{array}$ & $\begin{array}{r}32.391 .453 \\
16,44 \\
\end{array}$ & $\begin{array}{r}32.308 .794 \\
15,51 \\
\end{array}$ & $\begin{array}{r}-82.659 \\
-0,93 \\
\end{array}$ & $\begin{array}{l}99,74 \\
94,34 \\
\end{array}$ \\
\hline 10 & Interest charges & 62.797 & 20.514 & -42.283 & 32,66 \\
\hline 11 & Interest rate $(\mathrm{d})(10 / 9)(\%)$ & 0,19 & 0,06 & $-0,13$ & 31,57 \\
\hline 12 & Weighted average cost (Cmpc) (\%) & 6,859 & 8,885 & $+2,026$ & 129,53 \\
\hline 13 & $\begin{array}{l}\text { Economic added value (Vea) (6- } \\
12)^{*} 5\end{array}$ & -57.110 & -10.410 & +46.700 & 18,22 \\
\hline
\end{tabular}

On the basis of the data from Table no. 1, the following results are obtained:

$\mathrm{Vea}_{0}=\left(\mathrm{Ri}_{0}-\mathrm{Cmpc}_{0}\right) \times \mathrm{Ci}_{0}=(6,83-6,859) \times 196.930 .710=-57.110$ thousand lei

$\mathrm{Vea}_{1}=\left(\mathrm{Ri}_{1}-\mathrm{Cmpc}_{1}\right) \times \mathrm{Ci}_{1}=(8,88-8,885) \times 208.195 .930=-10.410$ thousand lei

1. Indicator modification is the difference:

$\Delta=$ Vea $_{1}-$ Vea $_{0}=-10.410-(-57.110)=+46.700$ thousand lei

$\left(\Delta \mathrm{r}=\mathrm{I}_{\text {lea }}-100=18,22-100=-81,78 \%\right)$

2.The influence factors are as follows:

In step I:

$\Delta=\Delta \mathrm{Ri}+\Delta \mathrm{Cmpc}+\Delta \mathrm{Ci}$

inwhich:

$\Delta \mathrm{Ri}=\left(\mathrm{Ri}_{1}-\mathrm{Ri}_{0}\right) \times \mathrm{Ci}_{0}=2,05 \times 196.930 .710=+4.037 .079$ thousand lei 
$\left(\Delta \mathrm{rRi}=\frac{\Delta \mathrm{Ri}}{\text { Vea }_{0}} \times 100=\frac{4.037 .079}{-57.110} \times 100=-7.068,25 \%\right)$

$\Delta \mathrm{Cmpc}=\left(\mathrm{Cmpc}_{0}-\mathrm{Cmpc}_{1}\right) \times \mathrm{Ci}_{0}=-2,026 \times 196.930 .710=-3.989 .816$ thousand lei

$\left(\Delta \mathrm{rCmpc}=\frac{\Delta \mathrm{Cmpc}}{\mathrm{Vea}_{0}} \times 100=\frac{-3.989 .816}{-57.110} \times 100=+6.986,19 \%\right)$

$\Delta \mathrm{Ci}=\left(\mathrm{Ri}_{1}-\mathrm{Cmpc}_{1}\right) \times\left(\mathrm{Ci}_{1}-\mathrm{Ci}_{0}\right)=(8,88-8,885) \times 11.265 .220=-563$ thousand lei

$\left(\Delta \mathrm{rCi}=\frac{\Delta \mathrm{Ci}}{\text { Vea }_{0}} \times 100=\frac{-563}{-57.110} \times 100=+0,98 \%\right)$

By addition we check the equality:

$\Delta \mathrm{Ri}+\Delta \mathrm{Cmpc}+\Delta \mathrm{Ci}=4.037 .079-3.989 .816-563=+46.700$ thousand lei $=\Delta$

$(\Delta \mathrm{rRi}+\Delta \mathrm{rCmpc}+\Delta \mathrm{rCi}=-7.068,25+6.989,19+0,98=-81,78 \%=\Delta \mathrm{r})$

\section{In step II}

The weighted average cost of capital ( $\mathrm{Cmpc}$ ), expressed as a percentage, represents the average total return on capital and is determined by means of the relation: $\mathrm{Cmpc}=\frac{[\operatorname{Scp} \times R f)+[\operatorname{Sddxd} \times[1-i]]}{100}$, where:

Scp = share capital ratio;

$\mathrm{Rf}=$ financial rate of return (on equity);

$\mathrm{Sd}=$ debt ration; $\mathrm{d}=$ interest rate; $\mathrm{i}=$ tax rate.

Consequently: $\Delta \mathrm{Cmpc}=\Delta \mathrm{Scp}+\Delta \mathrm{Rf}+\Delta \mathrm{Sd}+\Delta \mathrm{d}+\Delta \mathrm{I}$, where:

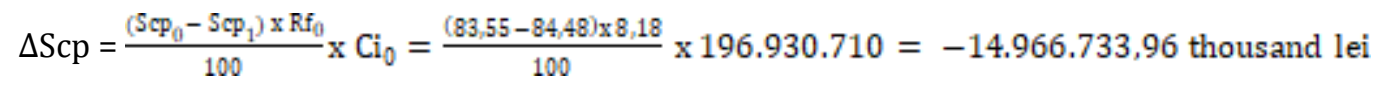

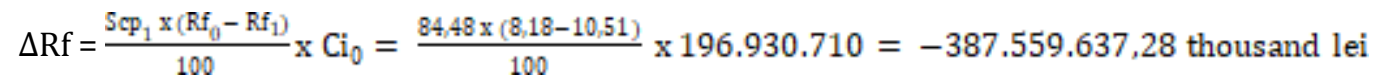

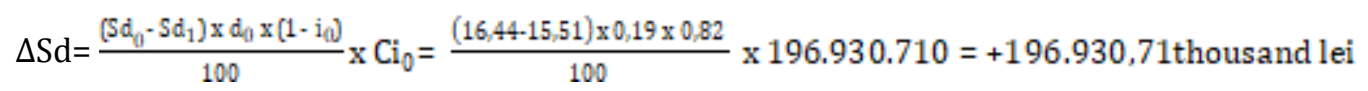

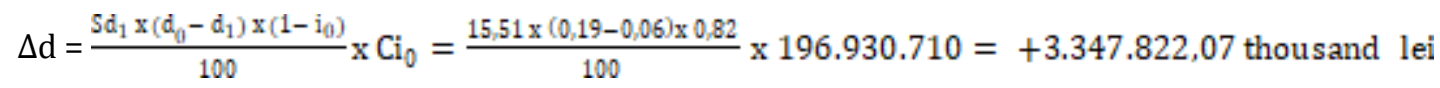

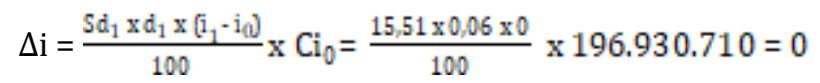

By addition we check the equality:

$\Delta \mathrm{Scp}+\Delta \mathrm{Rf}+\Delta \mathrm{Sd}+\Delta \mathrm{d}+\Delta \mathrm{i}=-14.966 .733,96-387.559 .637,28+196.930,71+3.347 .822,07+0=$ $=-3.989 .816$ thousand lei $=\Delta \mathrm{Cmpc}$

The economic added value had negative $81.78 \%$ decreasing values as a result of the average rate of return on total capital invested, which increased and exceeded the weighted average cost of capital.

The increase with $37.40 \%$ of the net operating profit, when the invested capital grew with only $5.72 \%$, favoured the growth of the average return rate (the average cost of the total capital) with $30.01 \%$, which increased the economic added value.

The 5.72\% invested capital increase, together with the negative difference decrease between the average capital return and the weighted average cost, increased the economic added value. As far as the cost of capital weighted average increase, which diminished the economic added value, is concerned, one may notice that this was a consequence of the increasing equity remuneration (the financial return rate) and its increasing weight in the conditions of debt remuneration decrease (by means of the interest rate) and its weight decrease within the invested capital.

The difference between the invested capital return rate growth $(2.05 \%)$ and the capital average weighted cost growth $(2.026 \%)$ resulted in the increase of the economic added value, which remained negative, which can be explained by the fact that in the calculation we used book values of the gross operating profit and of the invested capital.

\section{The EVA calculation and analysis for Ropharma S.A.}

Ropharma S.A. is a company that continues the Romanian pharmaceutical tradition. Ropharmais the main shareholder of Eurofarmaco S.A., after taking over the majority stake from the British company GSK. Ropharma's production portfolio includes over 50 products that cover over 21 therapeutic areas. Ropharma 
is the shareholder of one of the most modern medical units in the country, the multidisciplinary hospital "Sfântul Constantin" Brașov.

The applied economic added value calculation principle is the same as in the case of the company Biofarm S.A. The results of the calculations are presented below in Table no. 2 and were carried out on the basis of the financial information processing from the annual financial situations.

Table 2. The EVA calculation forRopharma S.A. for the time period 2017-2018

\begin{tabular}{|c|c|c|c|c|c|}
\hline \multirow[t]{2}{*}{ No. } & \multirow{2}{*}{$\begin{array}{c}\text { Indicators } \\
\text { (thousands of lei) }\end{array}$} & \multicolumn{2}{|c|}{ Financial year } & \multirow{2}{*}{$\begin{array}{l}\text { Deviation } \\
( \pm \Delta)\end{array}$} & \multirow{2}{*}{$\begin{array}{c}\text { Indices } \\
(\%)\end{array}$} \\
\hline & & 2017 & 2018 & & \\
\hline 1 & Gross operating profit (Rexp) & 9.589 .082 & 10.516 .880 & +927.798 & 109,67 \\
\hline 2 & Income tax (Ip) (-) & 2.198 .675 & 1.687 .724 & -510.951 & 76,76 \\
\hline 3 & Net operating profit (Bnop) & 7.390 .407 & 8.829 .156 & +1.438 .749 & 119,46 \\
\hline 4 & Tax rate (i) $(2 / 1)$ & 0,22 & 0,16 & $-0,06$ & 72,72 \\
\hline 5 & Total invested capital (Ci) & 358.187 .134 & 342.517 .910 & -15.669 .224 & 95,62 \\
\hline 6 & $\begin{array}{l}\text { Return on invested capital (Ri) } \\
(3 / 5)(\%)\end{array}$ & 2,06 & 2,57 & $+0,51$ & 124,75 \\
\hline 7 & $\begin{array}{l}\text { Shareholders' equity (C) }(7 / 5)^{*} 100 \\
-\quad \text { Share in total capital (Scp) }(\%)\end{array}$ & $\begin{array}{r}107.774 .583 \\
30,08 \\
\end{array}$ & $\begin{array}{r}114.164 .554 \\
33,33 \\
\end{array}$ & $\begin{array}{r}+6.389971 \\
+3,25 \\
\end{array}$ & $\begin{array}{l}105,92 \\
110,80\end{array}$ \\
\hline 8 & Return on equity (Rf) $(3 / 7)(\%)$ & 6,85 & 7,73 & $+0,88$ & 112,84 \\
\hline 9 & $\begin{array}{l}\text { Total debt (D) }(9 / 5) * 100 \\
-\quad \text { Share in total capital (Sd) (\%) }\end{array}$ & $\begin{array}{r}250.412 .551 \\
69,91 \\
\end{array}$ & $\begin{array}{r}228.353 .356 \\
66,66 \\
\end{array}$ & $\begin{array}{r}-22.059 .195 \\
-3,25 \\
\end{array}$ & $\begin{array}{l}91,19 \\
95,35 \\
\end{array}$ \\
\hline 10 & Interest charges & 1.600 .814 & 1.445 .344 & -155.470 & 90,28 \\
\hline 11 & Interest rate (d) (10/9) (\%) & 0,63 & 0,63 & 0 & 100,00 \\
\hline 12 & Weighted average cost (Cmpc) (\%) & 2,403 & 2,928 & $+0,525$ & 121,84 \\
\hline 13 & $\begin{array}{l}\text { Economic added value (Vea) (6- } \\
12)^{* 5}\end{array}$ & -1.228 .582 & -1.226 .214 & +2.368 & 99,80 \\
\hline
\end{tabular}

On the basis of the data from Table no. 2, the following results are obtained:

$\mathrm{Vea}_{0}=\left(\mathrm{Ri}_{0}-\mathrm{Cmpc}_{0}\right) \times \mathrm{Ci}_{0}=(2,06-2,403) \times 358.187 .134=-1.228 .582$ thousand lei

$\mathrm{Vea}_{1}=\left(\mathrm{Ri}_{1}-\mathrm{Cmpc}_{1}\right) \times \mathrm{Ci}_{1}=(2,57-2,928) \times 342.517 .910=-1.226 .214$ thousand lei

1. Indicator modification is the difference:

$\Delta=$ Vea $_{1}-$ Vea $_{0}=-1.226 .214-(-1.228 .582)=+2.368$ thousand lei

$\left(\Delta \mathrm{r}=\mathrm{I}_{\text {lea }}-100=99,80-100=-0,20 \%\right)$

2.The influence factors are as follows:

In step I:

$\Delta=\Delta \mathrm{Ri}+\Delta \mathrm{Cmpc}+\Delta \mathrm{Ci}$, where:

$\Delta \mathrm{Ri}=\left(\mathrm{Ri}_{1}-\mathrm{Ri}_{0}\right) \times \mathrm{Ci}_{0}=0,51 \times 358.187 .134=+1.826 .754$ thousand lei

$\left(\Delta \mathrm{rRi}=\frac{\Delta \mathrm{Ri}}{\mathrm{Vea}_{0}} \times 100=\frac{1.826 .754}{-1.228 .582} \times 100=-148,69 \%\right)$

$\Delta \mathrm{Cmpc}=\left(\mathrm{Cmpc}_{0}-\mathrm{Cmpc}_{1}\right) \times \mathrm{Ci}_{0}=-0,525 \times 358.187 .134=-1.880 .482$ thousand lei

$\left(\Delta \mathrm{rCmpc}=\frac{\Delta \mathrm{Cmpc}}{\mathrm{Vea}_{0}} \times 100=\frac{-1.880 .482}{-1.228 .582} \times 100=153,06 \%\right)$

$\Delta \mathrm{Ci}=\left(\mathrm{Ri}_{1}-\mathrm{Cmpc}_{1}\right) \times\left(\mathrm{Ci}_{1}-\mathrm{Ci}_{0}\right)=(2,57-2,928) \times(-15.669 .224)=+56.096$ thousand lei

$\left(\Delta \mathrm{rCi}=\frac{\Delta \mathrm{Ci}}{\mathrm{Vea}_{0}} \times 100=\frac{56.096}{-1.228 .582} \times 100=-4,57 \%\right)$

By addition we check the equality:

$\Delta \mathrm{Ri}+\Delta \mathrm{Cmpc}+\Delta \mathrm{Ci}=1.826 .754-1.880 .482+56.096=+2.368$ thousand lei $=\Delta$

$(\Delta \mathrm{rRi}+\Delta \mathrm{rCmpc}+\Delta \mathrm{rCi}=-148,69+153,06-4,57=-0,20 \%=\Delta \mathrm{r})$

\section{In step II}

The weighted average cost of capital $(\mathrm{Cmpc})$, expressed as a percentage, represents the average total return

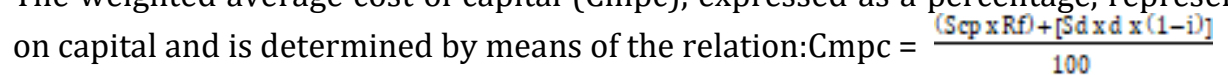

$\Delta \mathrm{Cmpc}=\Delta \mathrm{Scp}+\Delta \mathrm{Rf}+\Delta \mathrm{Sd}+\Delta \mathrm{d}+\Delta \mathrm{I}$, where 
$\Delta \mathrm{Scp}=\frac{\left[\mathrm{Scp}_{0}-\mathrm{Scp}_{1}\right) \mathrm{Rf}_{0}}{100} \mathrm{xCi}_{0}=\frac{-3.25 \times 6,85}{100} \times 358.187 .134=-79.517 .543,74$ thousand lei

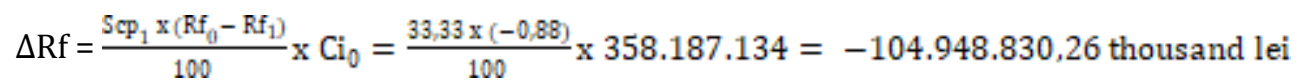

$\Delta \mathrm{Sd}=\frac{\left[S d_{0 j}-S d_{1}\right) \times d_{0} \times\left[1-i_{W}\right]}{100} \times C_{1}=\frac{3.25 \times 0,63 \times 0,78}{100} \times 358.187 .134=+7.163 .742,68$ thousand lei

$\Delta \mathrm{d}=\frac{\mathrm{Sd} \mathrm{d}_{1} \times\left[\mathbb{d}_{0}-\mathbb{d}_{1}\right) \times\left[1-\mathrm{i}_{0}\right]}{100} \mathrm{xCi}_{0}=\frac{66,66 \mathrm{x} 0 \mathrm{x} 0.78}{100} \times 358.187 .134=0$

$\Delta \mathrm{i}=\frac{5 a_{1} \times a_{1} \times\left[L_{1}-a_{0}\right)}{100} \mathrm{XCi}_{0}=\frac{66,66 \times 0,63 \times[-0,06)}{100} \times 358.187 .134=-10.745 .614,02$ thousand lei

By addition we check the equality:

$\Delta \mathrm{Scp}+\Delta \mathrm{Rf}+\Delta \mathrm{Sd}+\Delta \mathrm{d}+\Delta \mathrm{i}=-79.517 .543,74-104.948 .830,26+7.163 .742,68+0-10.745 .614,02=$

$=-1.880 .482$ thousand lei $=\Delta \mathrm{Cmpc}$

The economic added value had negative $0.20 \%$ decreasing values as a result of the average rate of return on total capital invested, which increased and exceeded the weighted average cost of capital.

The increase with $19.46 \%$ of the net operating profit, when the invested capital decreased with only $4.38 \%$, favoured the growth of the average return rate (the average cost of the total capital) with $24.75 \%$, which increased the economic added value.

The 4.38\% invested capital decrease, together with the negative difference decrease between the average capital return rate and the weighted average cost, increased the economic added value. As far as the cost of capital weighted average increase, which diminished the economic added value, is concerned, one may notice that this was a consequence of the increasing equity remuneration (the financial return rate) and its increasing weight in the conditions of debt remuneration stagnation (by means of the interest rate) and its weight decrease within the invested capital.

The difference between the invested capital return rate growth $(0.51 \%)$ and the capital average weighted cost growth $(0.525 \%)$ resulted in the increase of the economic added value, which remained negative, which can be explained by the fact that in the calculation we used book values of the gross operating profit and of the invested capital.

\section{The EVA calculation and analysis for Oil Terminal S.A.}

The company occupies a strategic position in the Black Sea Area, being the biggest sea operator, specialized in the circulation of oil, liquid petrochemical products and other raw materials to be imported or exported. Oil Terminal Constanța represents one of the biggest terminals in South-Eastern Europe.

In order to calculate the economic added value, the above-mentioned calculation technique was used and the obtained resultsare presented in Table no. 3:

Table 3. The EVA calculation for Oil Terminal S.A. for the time period 2017-2018

\begin{tabular}{|c|c|c|c|c|c|}
\hline \multirow[t]{2}{*}{ No. } & \multirow{2}{*}{$\begin{array}{c}\text { Indicators } \\
\text { (thousands of lei) }\end{array}$} & \multicolumn{2}{|c|}{ Financial year } & \multirow{2}{*}{$\begin{array}{l}\text { Deviation } \\
( \pm \Delta)\end{array}$} & \multirow{2}{*}{$\begin{array}{l}\text { Indices } \\
\text { (\%) }\end{array}$} \\
\hline & & 2017 & 2018 & & \\
\hline 1 & Gross operating profit (Rexp) & 2.021 .019 & 2.581 .360 & +560.341 & 127,72 \\
\hline 2 & Income tax (Ip) (-) & 1.059 .765 & 1.777 .027 & +717.262 & 167,68 \\
\hline 3 & Net operating profit (Bnop) & 961.254 & 804.333 & -156.921 & 83,67 \\
\hline 4 & Tax rate (i) $(2 / 1)$ & 0,52 & 0,68 & $+0,16$ & 130,76 \\
\hline 5 & Total invested capital (Ci) & 429.199 .530 & 471.274 .088 & +42.074 .558 & 109,80 \\
\hline 6 & $\begin{array}{l}\text { Return on invested capital (Ri) } \\
(3 / 5)(\%)\end{array}$ & 0,22 & 0,17 & $-0,05$ & 77,27 \\
\hline 7 & $\begin{array}{l}\text { Shareholders' equity (C) } \\
(7 / 5)^{*} 100 \\
-\quad \text { Share in total capital (Scp) (\%) }\end{array}$ & $\begin{array}{r}396.244 .467 \\
92,32\end{array}$ & $\begin{array}{r}437.815 .394 \\
92,90\end{array}$ & $\begin{array}{r}+41.570 .927 \\
+0,58\end{array}$ & $\begin{array}{l}110,49 \\
100,62\end{array}$ \\
\hline 8 & Return on equity (Rf) $(3 / 7)(\%)$ & 0,24 & 0,18 & $-0,06$ & 75,00 \\
\hline 9 & $\begin{array}{l}\text { Total debt (D) }(9 / 5)^{*} 100 \\
-\quad \text { Share in total capital }(\mathrm{Sd})(\%)\end{array}$ & $\begin{array}{r}32.955 .063 \\
7,67\end{array}$ & $\begin{array}{r}33.458 .694 \\
7,09\end{array}$ & $\begin{array}{r}+503.631 \\
-0,58\end{array}$ & $\begin{array}{r}101,52 \\
92,43\end{array}$ \\
\hline 10 & Interest charges & 521.275 & 656.212 & +134.937 & 125,88 \\
\hline 11 & Interest rate (d) (10/9) (\%) & 1,58 & 1,96 & $+0,38$ & 124,05 \\
\hline 12 & $\begin{array}{l}\text { Weighted average cost }(\mathrm{Cmpc}) \\
(\%)\end{array}$ & 0,279 & 0,211 & $-0,068$ & 75,62 \\
\hline 13 & $\begin{array}{l}\text { Economic added value (Vea) (6- } \\
12)^{* 5}\end{array}$ & -253.228 & -193.222 & +60.006 & 76,30 \\
\hline
\end{tabular}


On the basis of the data from Table no. 2, the following results are obtained:

Vea $_{0}=\left(\mathrm{Ri}_{0}-\mathrm{Cmpc}_{0}\right) \times \mathrm{Ci}_{0}=(0,22-0,279) \times 429.199 .530=-253.228$ thousand lei

Vea $_{1}=\left(\mathrm{Ri}_{1}-\mathrm{Cmpc}_{1}\right) \times \mathrm{Ci}_{1}=(0,17-0,211) \times 471.274 .088=-193.222$ thousand lei

1. Indicator modification is the difference:

$\Delta=$ Vea $_{1}-$ Vea $_{0}=-193.222-(-253.228)=+60.006$ thousand lei

$\left(\Delta \mathrm{r}=\mathrm{I}_{\text {lea }}-100=76,30-100=-23,70 \%\right)$

2. The influence factors are as follows:

In step I:

$\Delta=\Delta \mathrm{Ri}+\Delta \mathrm{Cmpc}+\Delta \mathrm{Ci}$, where:

$\Delta \mathrm{Ri}=\left(\mathrm{Ri}_{1}-\mathrm{Ri}_{0}\right) \times \mathrm{Ci}_{0}=-0,05 \times 429.199 .530=-214.600$ thousand lei

$\left(\Delta \mathrm{rRi}=\frac{\Delta \mathrm{Ri}}{\mathrm{Vea}_{0}} \mathrm{x} 100=\frac{-214.600}{-253.228} \times 100=+84,74 \%\right)$

$\Delta \mathrm{Cmpc}=\left(\mathrm{Cmpc}_{0}-\mathrm{Cmpc}_{1}\right) \times \mathrm{Ci}_{0}=0,068 \times 429.199 .530=+291.856$ thousand lei

$\left(\Delta \mathrm{rCmpc}=\frac{\Delta \mathrm{Cmpc}}{\mathrm{Vea}_{0}} \times 100=\frac{291.856}{-253.228} \times 100=-115,25 \%\right)$

$\Delta \mathrm{Ci}=\left(\mathrm{Ri}_{1}-\mathrm{Cmpc}_{1}\right) \times\left(\mathrm{Ci}_{1}-\mathrm{Ci}_{0}\right)=(0,17-0,211) \times 42.074 .558=-17.250$ thousandlei

$\left(\Delta \mathrm{rCi}=\frac{\Delta \mathrm{Ci}}{\mathrm{Vea}_{0}} \times 100=\frac{-17.250}{-253.228} \times 100=+6,81 \%\right)$

By addition we check the equality:

$\Delta \mathrm{Ri}+\Delta \mathrm{Cmpc}+\Delta \mathrm{Ci}=-214.600+291.856-17.250=60.006$ thousand lei $=\Delta$

$(\Delta \mathrm{rRi}+\Delta \mathrm{rCmpc}+\Delta \mathrm{rCi}=84,74-115,25+6,81=-23,70 \%=\Delta \mathrm{r})$

\section{In step II}

The weighted average cost of capital $(\mathrm{Cmpc})$, expressed as a percentage, represents the average total return

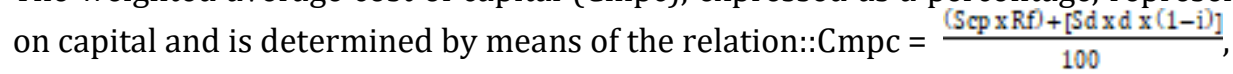

Consequently:

$\Delta \mathrm{Cmpc}=\Delta \mathrm{Scp}+\Delta \mathrm{Rf}+\Delta \mathrm{Sd}+\Delta \mathrm{d}+\Delta \mathrm{I}$, where

$\Delta \mathrm{Scp}=\frac{\left(\mathrm{Sep}_{0}-\mathrm{Sep}_{0}\right] \mathrm{xRf}_{0}}{100} \times \mathrm{Ci}_{0}=\frac{-0,58 \times 0,24}{100} \times 429.199 .530=-429.199,53$ thousand lei

$\Delta \mathrm{Rf}=\frac{\mathrm{Scp}_{1} \mathrm{x}\left[\mathrm{Rf}_{0}-\mathrm{Rf}_{\mathrm{i}}\right]}{100} \mathrm{xCl}_{0}=\frac{92,90 \mathrm{x} 0,06}{100} \times 429.199 .530=+23.605 .974,15$ thousand lei

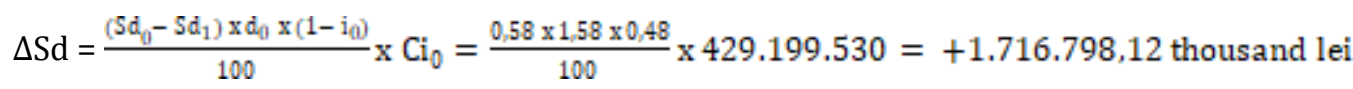

$\Delta \mathrm{d}=\frac{S \mathrm{~d}_{1} \mathrm{x}\left[\mathrm{d}_{0}-\mathrm{d}_{1}\right) \mathrm{x}\left[1-\mathrm{i}_{0}\right)}{100} \times \mathrm{Ci}_{0}=\frac{709 \mathrm{x}(-0,38) \times 0,48}{100} \times 429.199 .530=-5.150 .394,36$ thousand lei

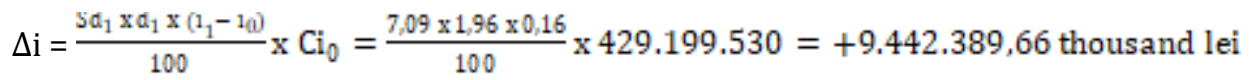

By addition we check the equality:

$\Delta \mathrm{Scp}+\Delta \mathrm{Rf}+\Delta \mathrm{Sd}+\Delta \mathrm{d}+\Delta \mathrm{i}=-429.199,53+23.605 .974,15+1.716 .798,12-5.150 .394,36+9.442 .389,66=$ $=+291.856 \mathrm{mii}$ lei $=\Delta \mathrm{Cmpc}$

The economic added value had negative $23.70 \%$ decreasing values as a result of the weighted average cost of capital, which decreased and didn't exceed the average return rate on total invested capital.

The decrease with $16.33 \%$ of the net operating profit, when the invested capital increased with only $9.80 \%$, disfavoured the decrease of the average return rate (the average cost of the total capital) with $22.73 \%$, which diminished the economic added value.

The 9.80\% invested capital increase, together with the negative difference decrease between the average capital return rate and the weighted average cost, increased the economic added value. As far as the cost of capital weighted average decrease, which increased the economic added value, is concerned, one may notice that this was a consequence of the increasing equity remuneration (the financial return rate) and its 
increasing weight in the conditions of debt remuneration growth (by means of the interest rate) and its weight decrease within the invested capital.

The difference between the invested capital return rate growth $(-0.05 \%)$ and the capital average weighted cost decrease $(-0.068 \%)$ resulted in the increase of the economic added value, which remained negative, which can be explained by the fact that in the calculation we used book values of the gross operating profit and of the invested capital.

\section{The comparative evolution charts for the three analysed companies:}
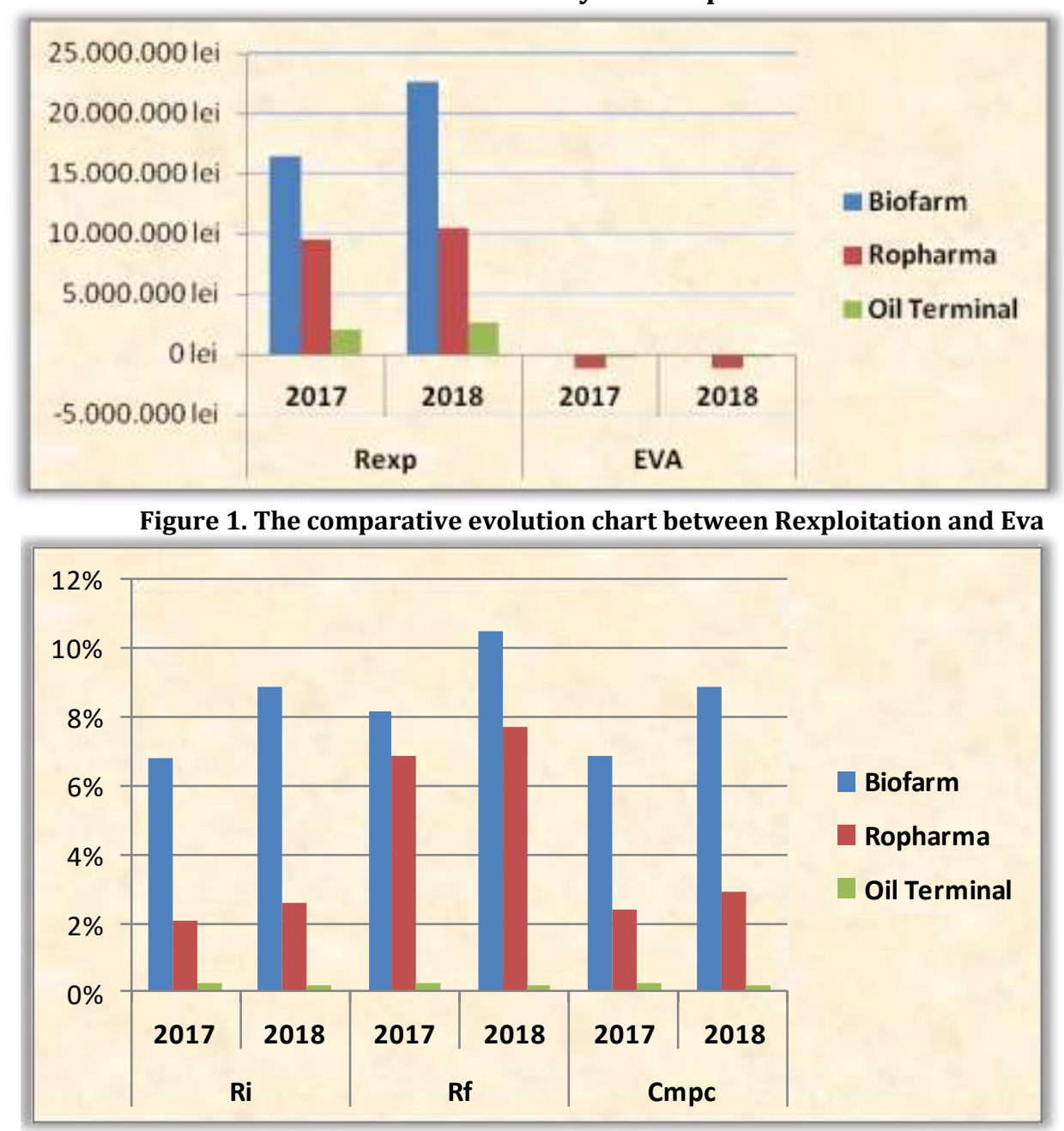

Figure 2. The comparative evolution chart between Rri, Rf, Cmpc

EVA may be determined both at the company's global level and at the level of different organisational subdivisions, production lines, no matter if the respective company is rated on the capital market or not.

Moreover, EVA allows for the company's performance calculation on periods of time shorter than a year because it is expressed according to the operating result sheet.

The conclusion of the present study as shown in the comparative charts for the three companies listed on the capital market resides in the fact that the main advantage of value-creating performance assessment is that it takes into consideration the cost of capital, that is to say the average return requested by investors, or it is calculated by relying on the market value, whereas the classic indicators are expressed only by means of historical results of the company's capital usage. EVA relies on the idea according to which a successful business must cover both the operating expenses and the costs of capital.

\section{Conclusion}

For capital holders and potential investors, the main target is not to obtain a positive EVA on a shortterm basis or at the end of the year, but to maintain constant or even increase the value of the economic profit. The value of the company will increase only if the EVA level achieved by the company in a certain period of time exceeds the investors' expectations regarding the level of this indicator.

EVA envisages the fact that any company must have as main purpose the shareholders' enrichment and, above all, that the company's value depends on the investors' motivation, who wish that future profit exceeds the cost of capital. 
Thus, EVA corresponds to a "residual income" of the shareholders. In addition, we can state that it is not the size of EVA that counts at a given moment, because the size in itself doesn't represent an indicator of the company's value because the current performance is best reflected in the share prices. EVA is first and foremost important on a long-term basis because it reflects the increase or decrease in shareholders'wealth.

\section{References}

1. Bărbulescu C., Dumitriu N.A., Probleme ale conducerii moderne a întreprinderilor productive, Editura Economică, București, 2008;

2. Bennett G. Stewart III, Best-Practice EVA: The Definitive Guide to Measuring and Maximizing Share holder Value, John Wiley \& Sons, Inc., Vol. 8, No. 1, United States, 2013;

3. Druică E., Risc și afaceri, Editura C.H.Beck, București, 2006;

4. Drury C., Management and cost accounting, 7th Edition, South-Western Cengage Learning, Canada, 2008;

5. Dumitrana M., Caraiani C., Control de gestiune, Editura Universitară, București, 2010;

6. Greceanu-Cocos V., Contabilitate aaplicată a întreprinderilor și microîntreprinderilor, EdituraUniversitară, București, 2014;

7. James L. Grant, Foundations of economic value-added, John Wiley \& Sons, Inc., NJ, USA, 2003;

8. Radu Riana Iren, Econometric Model-A tool in FinancialManagement, Annals of "Dunarea de Jos" University of Galati Fascicle I. Economics and Applied Informatics Years XVII - no2/2011 ISSN 1584-0409

9. Radu Riana Iren., The Analysis of Financial Conditions Imposed by Banks for the Approval of Long Term Credits Requested by Economical Agents, Ovidius University Annals, Economic Sciences Series, Ovidius University of Constantza, Faculty of Economic Sciences, vol. 0(2), pages 684-687, October, 2007

10. Pripoaie Rodica., Statistic Analysis of the Total Number of Banking Clients within Territorial Profile During 2002, International Conference on Finance and Risk, University of Economics in Bratislava, Slovakia, November 24-25, 2008

11. Pripoaie R., The Analyze and Prognose of Risk Bankruptcy - Case Study, Arcelor Mittal Steel Galati, MIBES Transactions International Journal, Management, Business \& Economic Systems, 2008

12. Sarbapriya Ray published an article, Efficacy of Economic Value Added Concept in Business Performance Measurement in the journal of Advances in Information Technology and Management (AITM), Vol. 2, No. 2, World Science Publisher, United States, 2012;

13. Shimin Chen and James L. Dodd published an article, Economic Value Added (EVA $\left.{ }^{\text {TM}}\right)$ : An Empirical Examination Of A New Corporate Performance Measure in the Journal of Managerial Issues, Vol. 9, No. 3 (Fall 1997), pp. 318-333, United States, 1997;

14. Sichigea N., Vasilescu L., Berceanu D., Florea N., Gestiuneafinanciară a întreprinderii, EdituraUniversitaria, Craiova, 2013;

15. Siminica M., Diagnosticul financiar al firmei, Editura Universitaria, Craiova, 2014;

16. Spătaru L., Analiza economico-financiară. Instrument al managementului întreprinderilor, Ediţia a II-a, Editura Economică, Bucureşti, 2010;

17. Spencer, Pickett, K., H., The Internal Auditing Handbook, Second Edition, Editura John Wiley\&Sons, III, River Street, Hoboken, NY 07030, USA, 2006;

18. Vâlceanu Gh., Robu V., Georgescu N., Analiza economico-financiară, Ediția a doua revizuită și adăugită, Editura Economică, București, 2005;

19. Verboncu I., Zalman M., Management și performanțe, EdituraUniversitară, București, 2005. 